\title{
Occurrence and mechanisms of formation of a dramatic thin layer of marine snow in a shallow Pacific fjord
}

\author{
Alice L. Alldredge ${ }^{1, *}$, Timothy J. Cowles ${ }^{3}$, Sally MacIntyre ${ }^{2}$, Jan E. B. Rines ${ }^{4}$, \\ Percy L. Donaghay ${ }^{4}$, Charles F. Greenlaw ${ }^{5}$, D. V. Holliday ${ }^{5}$, Margaret M. Dekshenieks ${ }^{4, * *}$, \\ James M. Sullivan ${ }^{4}$, J. Ronald V. Zaneveld ${ }^{3}$ \\ ${ }^{1}$ Department of Ecology, Evolution and Marine Biology, and ${ }^{2}$ Marine Science Institute, University of California, \\ Santa Barbara, California 93106, USA \\ ${ }^{3}$ College of Oceanic and Atmospheric Sciences, Oregon State University, Corvallis, Oregon 97331-5503, USA \\ ${ }^{4}$ Graduate School of Oceanography, University of Rhode Island, Narragansett, Rhode Island 02882-1197, USA \\ ${ }^{5}$ BAE Systems, 4669 Murphy Canyon Road, Suite 102, San Diego, California 92123-4333, USA
}

\begin{abstract}
Huge accumulations of diatom-dominated marine snow (aggregates $>0.5 \mathrm{~mm}$ in diameter) were observed in a layer approximately $50 \mathrm{~cm}$ thick persisting over a $24 \mathrm{~h}$ period in a shallow fjord in the San Juan Islands, Washington, USA. The layer was associated with the $22.4 \sigma_{\mathrm{t}}$ density surface. A second thin layer of elevated phytoplankton concentration located at a density discontinuity 1.5 to $2 \mathrm{~m}$ above the marine snow layer occurred within a dense diatom bloom near the surface. At the end of the study period, isopycnals shoaled and the 2 layers merged. More than $80 \%$ of the diatom bloom consisted of Thalassiosira spp. (50 to 59\%), Odontella longicruris (5 to 14\%), Asterionellopsis glacialis, and Thalassionema nitzschioides. A much higher proportion of O. longicruris occurred in marine snow (about 53\%) than among suspended cells suggesting that this species differentially aggregated. Most zooplankton avoided the mucus-rich aggregate layer. The layer of marine snow was formed when sinking aggregated diatoms reached neutral buoyancy at the 22.4 isopycnal, probably due to the presence of low salinity mucus resistant to salt exchange in the interstices of the aggregates. Rates of turbulent kinetic energy dissipation throughout the water column rarely exceeded $10^{-8} \mathrm{~m}^{2} \mathrm{~s}^{-3}$ and aggregates below the thin layer were largely detrital in composition indicating that small-scale shears due to turbulence did not erode the layer of marine snow. The accumulation of marine snow and phytoplankton in persistent, discrete layers at density discontinuities results in habitat partitioning of the pelagic zone, impacts the distribution and interactions of planktonic organisms as well as the intensity and location of biological processes in the water column, and helps maintain species diversity.
\end{abstract}

KEY WORDS: Thin layers - Marine snow - Diatom bloom flocculation - Density discontinuity · Plankton patchiness $\cdot$ Plankton distribution

\section{INTRODUCTION}

Layers of phytoplankton and zooplankton ranging from a few $\mathrm{cm}$ to a few $\mathrm{m}$ thick and extending up to

\footnotetext{
*E-mail: alldredg@lifesci.ucsb.edu

${ }^{* *}$ Present address: Ocean Sciences Department, University of California, Santa Cruz, California 95064, USA
}

many $\mathrm{km}$ horizontally have now been reported in a variety of marine systems including estuaries (Donaghay et al. 1992), coastal shelves (Cowles \& Desiderio 1993), fjords (Holliday et al. 1998, Dekshenieks et al. 2001), and open ocean waters (Bjornsen \& Nielsen 1991, Carpenter et al. 1995). These spatially and temporally coherent 'thin layers' can last for days (Dekshenieks et al. 2001, Rines et al. 2002). As sites of highly concentrated 
biological activity, thin layers may have an inordinately important, but as yet largely unquantified, impact on the biological and chemical dynamics of the marine pelagic zone. These layers may be subject to elevated levels of nutrient uptake, increased intensity of competition and predation, higher accumulation of chemical wastes and toxins, and higher levels of microbial degradation and remineralization than found in the seawater immediately above and below them (Mason et al. 1993, Sieburth \& Donaghay 1993, Johnson et al. 1995, Donaghay \& Osborn 1997, Cowles et al. 1998). They may also produce vertical patchiness in the optical (Zaneveld \& Pegau 1998) and acoustical (Holliday et al. 1998) properties of the water column and provide a mechanism for maintenance of species diversity and habitat partitioning in the pelagic zone.

Previous research on thin layers as sources of smallscale structure in the pelagic environment has focused primarily on phytoplankton and zooplankton distributions, and on optical and acoustical properties. However, accumulations of macroscopic aggregates of detrital particulate matter $>0.5 \mathrm{~mm}$ in diameter, known as marine snow, have also been documented to occur as thin layers off California (MacIntyre et al. 1995) and in the Adriatic Sea (Stachowitsch et al. 1990, Degobbis et al. 1997). Herndl \& Peduzzi (1988) sampled a thin layer of marine snow 10 to $50 \mathrm{~cm}$ thick resting on the pycnocline in the Adriatic Sea and found that the dry weight of the marine snow in this layer was enriched 7 times over that in the water column above the layer.

Since marine snow contains a significant fraction of non-living organic matter, the mechanisms by which aggregates accumulate to form thin layers may be considerably different from those of living organisms such as phytoplankton and zooplankton. Moreover, since aggregates of marine snow experience enhanced microbial activity, are enriched in chlorophyll and other pigments, and serve as food sources for many zooplankton (Alldredge \& Silver 1988), the occurrence of thin layers of marine snow may be 1 cause of layered distributions of associated organisms. Despite their potential significance, little is known about the occurrence of marine snow in thin layers, the processes that form them, or the impact of these thin layers on the distribution of other constituents in the water column. In this paper, we present the first extensive investigation of a thin layer of marine snow, and the distributions of phytoplankton and zooplankton asso- ciated with it. We discuss the possible mechanisms of formation of marine snow thin layers and their potential impact on the ecology of the water column.

\section{MATERIALS AND METHODS}

Study site. We investigated a persistent thin layer of marine snow and associated physical and biological properties of the water column on May 30 and June 1, 1996 while anchored in East Sound, Washington, USA $\left(48^{\circ} 38.24^{\prime} \mathrm{N}, 122^{\circ} 52.59^{\prime} \mathrm{W}\right.$; Fig. 1). East Sound is a shallow fjord, approximately $12 \mathrm{~km}$ long by 1 to $2.5 \mathrm{~km}$ wide and averaging $30 \mathrm{~m}$ in depth, located at Orcas Island in the San Juan Archipelago, Washington, USA. It has a tidal range of 0.3 to $3.5 \mathrm{~m}$. In the spring and early summer during periods of strong winds from the north and high melt water runoff, a plume of fresher, warmer water generated by the Fraser River, $23 \mathrm{~km}$ north on the Canadian mainland, can be advected into the sound, overriding the colder, more saline water found there and displacing it to depth. Such an event occurred on May 27, 4 d prior to this study (Dekshenieks et al. 2001, Twardowski \& Donaghay 2001).

Water column physical and chemical properties. Tidal height was recorded by an Endico tide gauge in Rosario Harbor, $0.8 \mathrm{~km}$ from the study site. Vertical profiles of temperature, salinity, density, fluorescence, particulate absorption, and turbulent kinetic energy dissipation were obtained over the $24 \mathrm{~h}$ study period

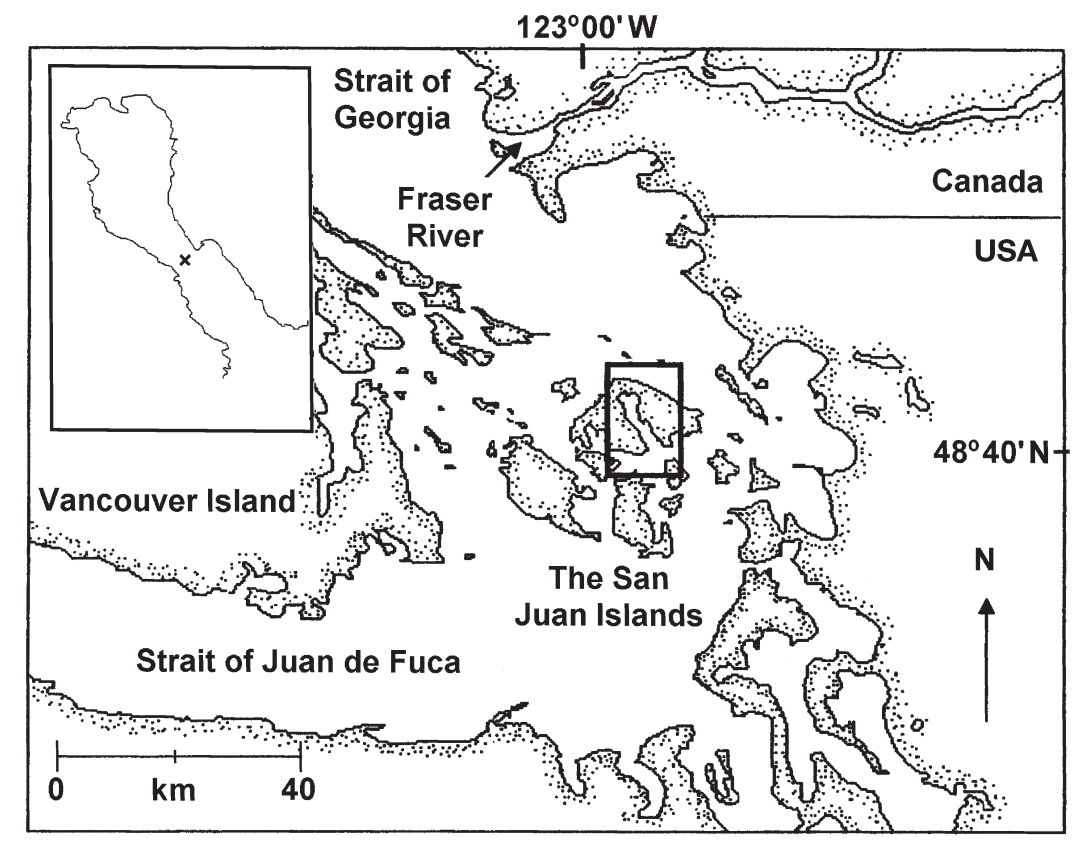

Fig. 1. Location of the study site (shown as an $x$ ) in East Sound in the San Juan Islands, Washington, USA 
from a free-falling instrument package that resolved physical, optical, and biological features simultaneously over small vertical scales of 2 to $3 \mathrm{~cm}$. Repeated profiles (approximately $10 \mathrm{~h}^{-1}$ ) provided the time series necessary to define the persistence of small-scale features. The package configuration consisted of a SeaBird 911+ CTD (conductivity, temperature, depth), a multi-wavelength absorption and attenuation meters (ac-9, WET Labs), a Sea-Tech fluorometer, and a temperature-gradient microstructure profiler (SelfContained Autonomous Microstructure Profiler or SCAMP, Precision Measurement Engineering) for estimation of turbulent kinetic energy dissipation and mixing intensity. Methods for analysis of the microstructure data are presented in MacIntyre et al. (1999).

A separate high resolution profiling system, deployed from a second vessel anchored about $100 \mathrm{~m}$ away, consisted of a Sea-Bird $911^{+}$CTD, 2 multi-wavelength absorption and attenuation meters (WET Labs ac-9), and a SAFIRE (WET Labs). The spectral absorption by dissolved substances was measured with 1 dual channel WET Labs ac-9 absorption meter equipped with a $0.2 \mu \mathrm{m}$ filter at the same time total spectral absorption and attenuation by dissolved plus particulate material was measured by a second ac-9. Spectral absorption by particulate material was then calculated by difference. Particle absorption at $440 \mathrm{~nm}\left(a_{\mathrm{p}} 440\right.$; the primary wavelength of absorption by chl a) was used as a proxy for phytoplankton biomass. Details of methodology, calibration, and data analysis are given by Twardowski et al. (1999) and Twardowski \& Donaghay (2001).

Marine snow. Seven vertical profiles of the abundance and size distributions of aggregates $>500 \mu \mathrm{m}$ in diameter were obtained over the $24 \mathrm{~h}$ period by photographing undisturbed particles in situ in a collimated slab of light. The system, described in MacIntyre et al. (1995), consisted of a Photosea $500035 \mathrm{~mm}$ still camera, Photosea 1550S strobe, and a CTD for determination of depth and intercomparison with the free-falling package described above. The camera package and free-falling package were deployed simultaneously from opposite ends of the first, $15 \mathrm{~m}$ vessel. Each camera profile yielded 180 to 200 photographs with a depth accuracy of $10 \mathrm{~cm}$ and no overlap of imaged fields. A frame size of $35 \times 25 \times$ $5 \mathrm{~cm}$ (4.4 l) was photographed for each image. Images were recorded on T-max 400 ASA black and white film (800 exposure rolls). All aggregates $>0.065 \mathrm{~mm}^{3}$ equivalent spherical volume (ESV; $0.5 \mathrm{~mm}$ diameter) contained in the photographs were counted and sized using computerized image analysis as described in Macintyre et al. (1995), and vertical profiles of cumulative aggregate volume, mean aggregate size and total aggregate number $\mathrm{l}^{-1}$ were constructed from each cast.
Zooplankton abundance. Total mesozooplankton biovolume, an analog of zooplankton displacement volume and an estimate of zooplankton biomass, were measured with a mini-Tracor Acoustical Profiling System (mini-TAPS; BAE Systems) lowered about once per hour over the $24 \mathrm{~h}$ period simultaneously with the other 2 profiling instruments. The mini-TAPS used 2 frequencies, 1.1 and $3 \mathrm{MHz}$. A 2-frequency inverse algorithm (Greenlaw 1979) estimated biovolume and the locations of dominant scatterer size. Zooplankton abundance was also determined by SCUBA divers who hand-towed $30 \mathrm{~cm}, 333 \mu \mathrm{m}$ mesh nets above, immediately within, and 2 to $3 \mathrm{~m}$ below the layer of marine snow at 12:00 and 00:00 $\mathrm{h}$. The position of the net relative to the marine snow layer was maintained visually and divers swam 2 replicate $40 \mathrm{~m}$ transects at each depth. Zooplankton samples were preserved in $70 \%$ ethanol and later enumerated with a dissecting microscope.

Phytoplankton composition. Water samples were collected from discrete depths between 0 and $30 \mathrm{~m}$ between 19:00 and 22:00 $\mathrm{h}$ to assess phytoplankton in the water column utilizing a siphon tube attached to the profiling system on the second vessel, as detailed by Donaghay et al. (1992). All samples were immediately examined live, aboard ship under a Zeiss WL microscope using phase contrast microscopy. Archival images of each live sample were recorded on videotape. Whole water samples were preserved with Formalin for subsequent enumeration of phytoplankton cells. One $\mathrm{ml}$ aliquots were later counted in a Sedgwick-Rafter chamber.

Six large aggregates were hand-collected by a diver at 12:00 $\mathrm{h}$ from the densest part of the marine snow layer using a single $250 \mathrm{ml}$ sampling jar. The aggregates collided to form 1 large conglomerate in the jar. A portion of this conglomerate was subsampled by pipette, placed on a microscope slide, and examined on the Zeiss WL microscope using phase contrast and bright field optics. The slide was scanned and an archival image recorded on videotape. Taxonomic composition of the aggregate was determined by freezing the video image on 40 random fields and counting the cells present.

\section{RESULTS}

\section{Description of the marine snow thin layer}

On the morning of May 31, an extremely dense thin layer of marine snow, about $50 \mathrm{~cm}$ thick, occurred at a depth of $5 \mathrm{~m}$ in East Sound (Fig. 2). Neither this layer nor abundant aggregates were observed by divers on any of the preceding $4 \mathrm{~d}$. The thin layer persisted for 

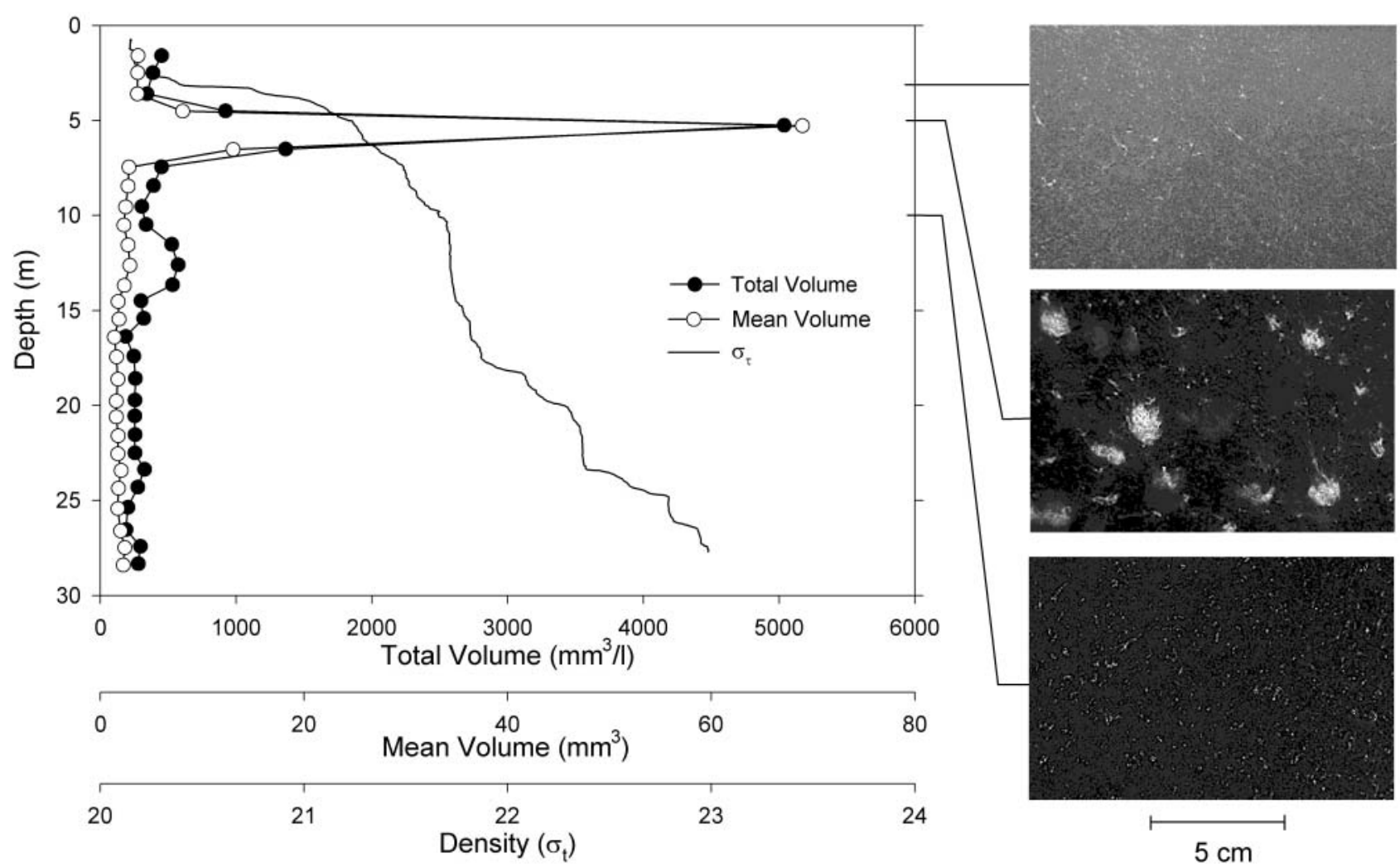

Fig. 2. The vertical distribution of total cumulative volume of aggregates $>0.5 \mathrm{~mm}$ in diameter and mean individual aggregate volume in relationship to seawater density $\left(\sigma_{t}\right)$ at 11:00 h on May 31, 1996. The thin layer was dominated by very large diatom aggregates while the water above it contained primarily individual diatom chains and cells and the water below contained primarily small detrital aggregates

$24 \mathrm{~h}$ and was still present when the study was terminated at 12:00 h on June 1. The layer consisted of large aggregates, many $>1 \mathrm{~cm}$ in diameter, formed from a variety of chain-forming diatom species. An extraordinarily dense diatom bloom occurred within and immediately above the layer. Small aggregates occurred within this surface bloom, and increased in size and abundance as the depth of the thin layer was approached from above. Aggregates and free-living cells were sparse below this layer (Fig. 2). Examination of these deeper particles microscopically and directly by divers indicated that they were older (containing more detritus and fecal matter and few diatoms) and highly disaggregated. The transition between the clear water below the snow layer and the bottom boundary of the turbid thin layer was only 1 to $2 \mathrm{~cm}$ thick as observed by divers.

The total cumulative volume of aggregates $>0.5 \mathrm{~mm}$ in diameter within the thin layer reached $5000 \mathrm{~mm}^{3} \mathrm{l}^{-1}$, an order of magnitude more concentrated than the rest of the water column (Fig. 3A). Aggregates made up about $0.5 \%$ of the volume of the water column at the thin layer depth and $<0.05 \%$ elsewhere in the water column. Total abundance of aggregates ranged from
25 to about 250 aggregates $\mathrm{l}^{-1}$ throughout the water column and varied considerably with time of day and depth. Thin layers of high aggregate abundance (in contrast to high aggregate cumulative volume) were not observed at any depth in the water column (Fig. 3B). Mean aggregate size at the depth of peak cumulative aggregate volume ranged from 2.9 to $5 \mathrm{~mm}$ diameter (13 to $85 \mathrm{~mm}^{3}$ in volume) over the $24 \mathrm{~h}$ study period (Fig. 3C), with maximum aggregate diameters reaching $>2 \mathrm{~cm}$ (Fig. 2). Thus, the thin layer of marine snow resulted from the accumulation of relatively rare but very large diatom flocs, producing a distinct layer of high cumulative aggregate volume, rather than from the accumulation of a large number of smaller aggregates (Fig. 3).

\section{Composition of free-living and aggregated phytoplankton}

While Thalassiosira spp. made up 50 to $59 \%$ of the diatom cells blooming in the surface layer (upper $4 \mathrm{~m}$ ), diatom aggregates in the thin layer were only $29 \%$ Thalassiosira (Fig. 4). Thalassionema nitzschioides and 
Asterionellopsis glacialis were also relatively rare in the aggregates ( $<7 \%$ total), although they contributed 12 to $19 \%$ each to the total cells in the surface layer. Odontella longicruris made up $53 \%$ of the diatoms in the aggregates but only 5 to $14 \%$ of the cells within the bloom in the upper layer suggesting differential aggregation of this species to form flocs. Skeletonema costatum (3\%) and Chaetoceros debilis (6\%) made up $9 \%$ of the phytoplankton in the aggregates (included in 'Other' on Fig. 4). Bulk water samples collected within the snow layer reflected the concentration of species within the aggregates, not those in the overlying water, indicating that aggregated diatoms, not free-living ones, determined diatom composition within the layer (Fig. 4).
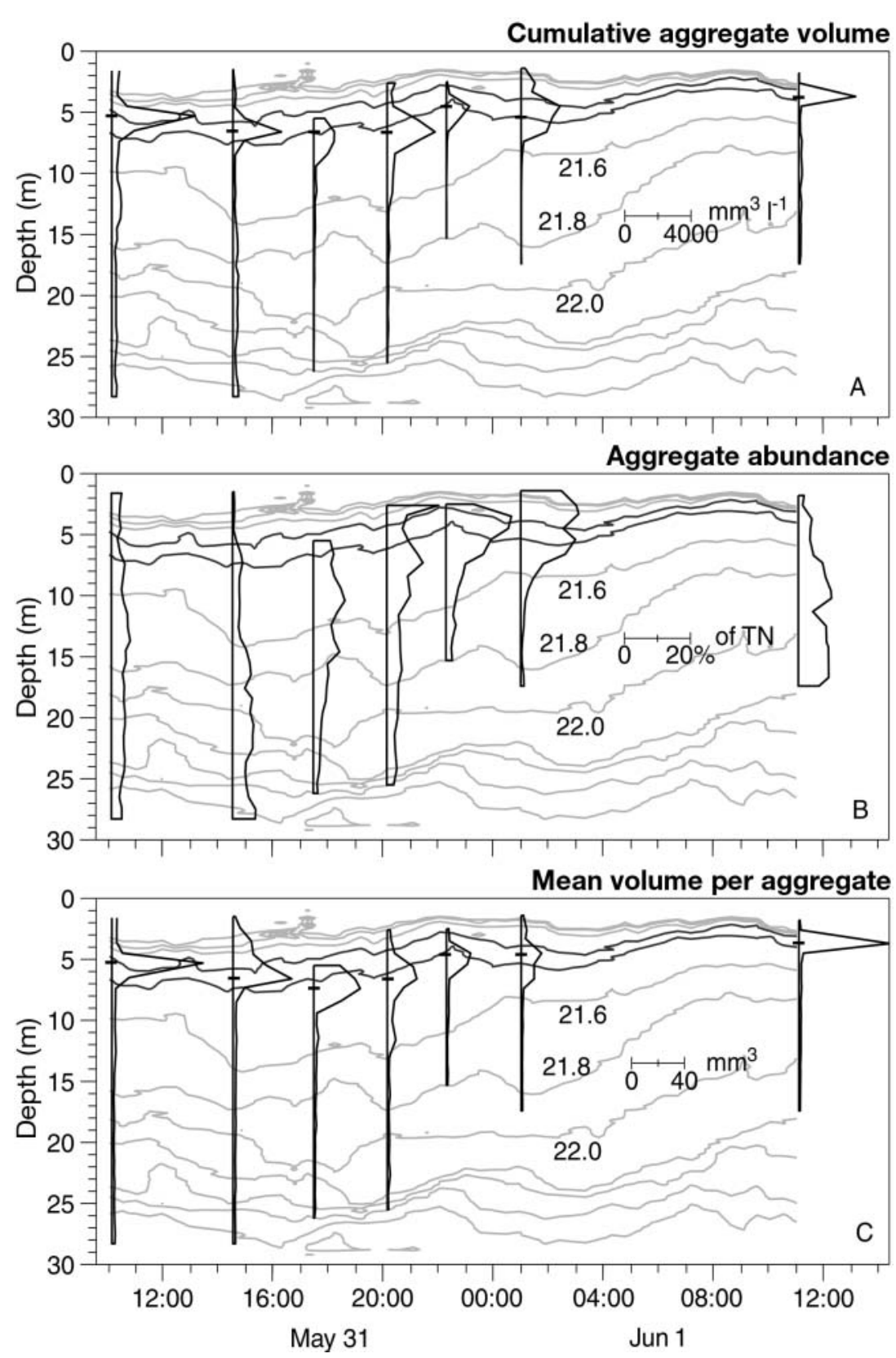

Fig. 3. Vertical distribution of marine snow over the $24 \mathrm{~h}$ study. Seawater density isopycnals $\left(\sigma_{t}\right)$ are shown as horizontal gray lines at intervals of 0.2 units. The depth of the aggregate maximum at each sampling time is indicated by the tick mark on each vertical axis. (A) Total cumulative aggregate volume in $\mathrm{mm}^{3} \mathrm{l}^{-1}$; (B) aggregate number concentration shown as the percent of total water column abundance found at each depth; $(C)$ mean individual aggregate volume in $\mathrm{mm}^{3}$

\section{Location of the marine snow thin layer in relation to physical and chemical variables}

The water column at East Sound consisted of a shallow, fresher, warmer layer up to $5 \mathrm{~m}$ deep resting on a more saline, colder layer extending to the bottom (Fig. 5). The 2 regions were separated by a sharp pycnocline at 3 to $5 \mathrm{~m}$. The pycnocline closely followed the salinity contours (Fig. 5B,C) indicating that salinity played a major role in determining the density distribution. A layer of high phytoplankton abundance averaging $60 \mathrm{~cm}$ in thickness, as measured by particulate absorption at $440 \mathrm{~nm}$ and fluorescence, occurred at 3 to $5 \mathrm{~m}$, depending upon the time of day (Fig. 6A). The particulate absorption data indicate that fine suspended particles were initially located between isopycnals of 20.6 to $21.0 \sigma_{t}$ at concentrations greater than 3 to 5 times background concentrations. By mid-afternoon on the first day, they rested on the 21.0 to 21.2 isopycnal. After 04:00 h on June 1 the near-surface isopycnals all shoaled and the high absorbance layer also became shallower, although it rested on the 21.2 to 21.4 isopycnal during this time (Fig. 6A).

The marine snow layer occurred consistently about 1.5 to $2 \mathrm{~m}$ below the layer of high particulate absorption and fluorescence, except at the very last sampling point when the snow layer and phytoplankton layers coincided (Figs. 3A \& 6). Maximum cumulative marine snow volume and maximum mean aggregate size occurring at the 21.2 to 21.4 isopycnal throughout the study. Both the layer of high particulate absorption and the marine snow layer tended to occur at small discontinuities in the density profile (Fig. 4). 


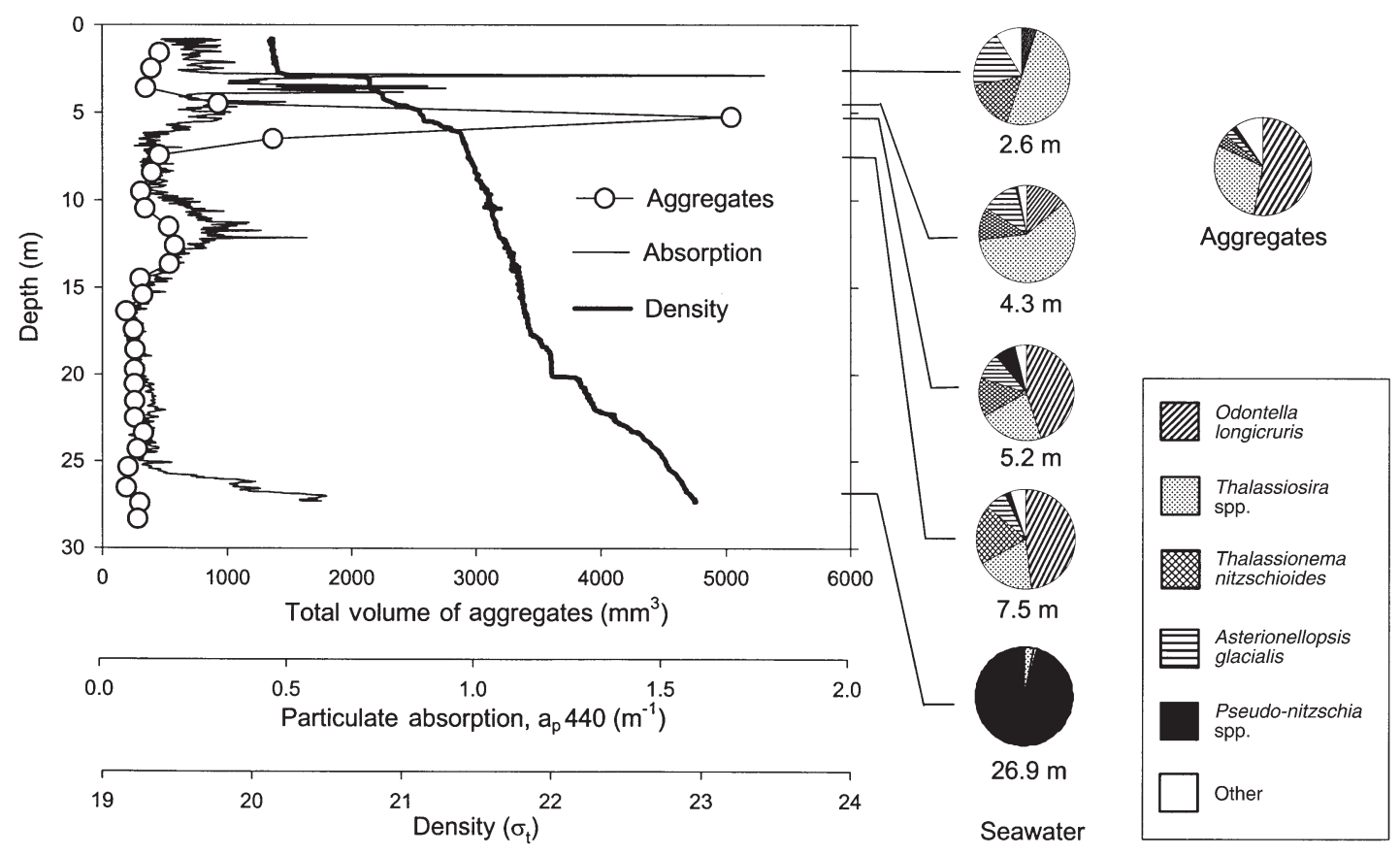

Fig. 4. The position of the thin layer, shown as cumulative aggregate volume, in relationship to seawater density $\left(\sigma_{t}\right)$ and particulate absorption at $440 \mathrm{~nm}$ at 11:00 h on May 31, 1996. The phytoplankton thin layer occurred about $2 \mathrm{~m}$ above the marine snow thin layer. Diatom community composition varied considerably throughout the water column as indicated by the pie diagrams

Wind velocities over the course of the study were very low, consistently $<1.0$ to $1.5 \mathrm{~m} \mathrm{~s}^{-1}$ until about 04:00 h on June 1 when velocity increased slightly to $4 \mathrm{~m} \mathrm{~s}^{-1}$ for about $15 \mathrm{~min}$ and then returned to 1 to $2 \mathrm{~m} \mathrm{~s}^{-1}$ (data not shown). Energy dissipation was low throughout the water column throughout the study. Rates of turbulent kinetic energy dissipation at the depths characterized by accumulations of marine snow and at greater depths in the water column rarely exceeded $10^{-8} \mathrm{~m}^{2} \mathrm{~s}^{-3}$ (Fig. 7). The region from 5 to $7 \mathrm{~m}$ containing the marine snow layer tended to have consistently low turbulence; only $9 \%$ of the time was turbulent energy dissipation in this region $>10^{-8} \mathrm{~m}^{2} \mathrm{~s}^{-3}$. Consequently, it is unlikely that small-scale shears due to turbulence caused disaggregation of the layer of marine snow or produced the sharply defined lower boundary of the layer by erosion. While infrequent, rates of turbulent kinetic energy at depths where phytoplankton abundances were higher did occasionally exceed $10^{-6} \mathrm{~m}^{2} \mathrm{~s}^{-3}$ (Fig. 7).

A mixed, semidiurnal tidal flow occurred during the study (Fig. 8). Near the end of the study the tide ebbed sharply. Both marine snow and fine particle thin layers shoaled during this last ebb tide, but this shoaling was related to the intrusion of a wedge of warmer, higher saline water entering the study site near the bottom at about 01:00 h. This warm water intrusion, clearly visible on the temperature and salinity time series (Fig. $5 \mathrm{~A}, \mathrm{~B}$ ), resulted in the shoaling of the density isopycnals throughout most of the water column (Fig. 5C) and the concurrent movement of the thin layers closer to the surface during the last hour of the study. The positions of the thin layers were not related to tidal flow.

\section{Location of the thin layer in relation to zooplankton}

Zooplankton biovolume, as measured acoustically, was concentrated in the surface layer from 0 to $5 \mathrm{~m}$ and consistently occurred above the marine snow layer throughout the study. A slight migration upward at night resulted in maximum biovolumes between 0 and $3 \mathrm{~m}$ depths during that time (Fig. 9). Direct measurements of zooplankton abundance above, within and below the marine snow layer with nets was consistent with the acoustic results. There was 4 times more zooplankton at $2 \mathrm{~m}$ than within the marine snow layer at $6 \mathrm{~m}$ both at 12:00 and 00:00 h (Fig. 10). Total zooplankton abundance increased again below the snow layer although it still remained at about $1 / 3$ to $1 / 2$ of the abundance in the surface layer. This pattern of maximum abundance in the surface layer and minimum abundance within the marine snow layer was observed for most taxa including total zooplankton, larvaceans, copepods, cyprid larvae, crustacean nauplii, euphausiid zoea, echinoderm larvae, cladocerans, ostracods, and chaetognaths. Medusa, ctenophores, siphono- 

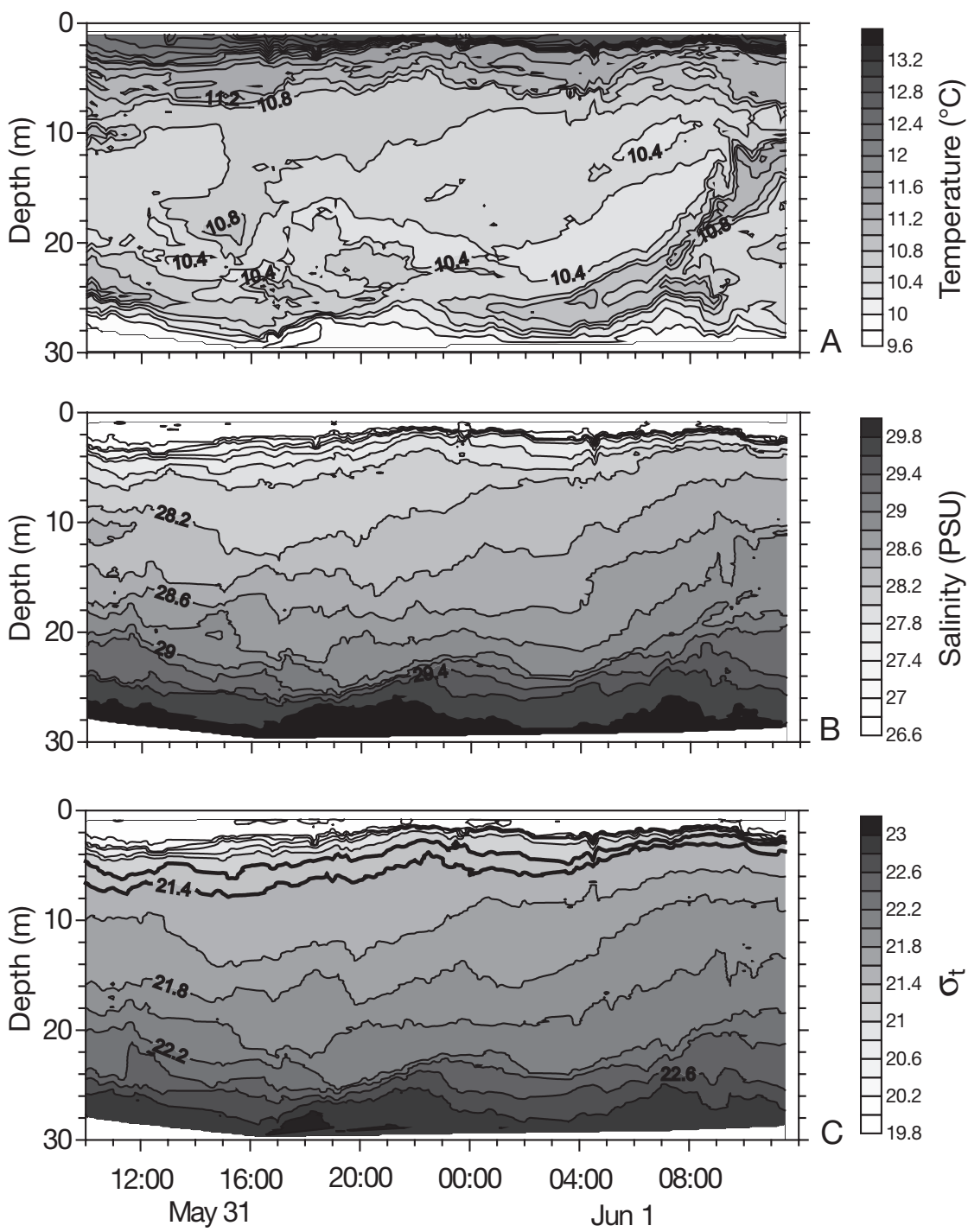

Fig. 5. Water column properties over the $24 \mathrm{~h}$ study. (A) Temperature $\left({ }^{\circ} \mathrm{C}\right)$; (B) salinity $(\mathrm{psu})$; (C) seawater density $\left(\sigma_{\mathrm{t}}\right)$. The 21.2 and 21.4 isopycnals are highlighted

phores and most crab larvae tended to occur in highest abundances below the marine snow layer and at minimum abundances within it. Only polychaete larvae and Porcellanid crab larvae occurred in higher abundances within the marine snow layer.

\section{DISCUSSION}

Accumulations of marine snow 3 to $10 \mathrm{~m}$ in thickness associated with density discontinuities have been described previously (MacIntyre et al. 1995), but most of these have not been considered thin layers. True thin layers of marine snow 10 to $50 \mathrm{~cm}$ thick have only been qualitatively described and sampled by divers in the northern Adriatic Sea in 1986 (Herndl \& Peduzzi 1988) and in 1991 (Degobbis et al. 1997). The layers accumulated at the pycnocline and periodic disruption of stratification led to their sedimentation to the sea floor. Marine snow appearing like a false bottom at the pycnocline has been observed by divers at other times as well (Stachowitsch et al. 1990, Degobbis et al. 1997) suggesting that the formation of thin layers of diatom-dominated marine snow similar to the one observed in East Sound are common in the Adriatic Sea.

\section{Possible mechanisms of marine snow thin layer formation}

The extensive physical and biological data collected during the week prior to this study (Twardowski \& Donaghay 2001, Dekshenieks et al. 2001, Rines et al. 2002) allowed us to generate hypotheses regarding thin layer formation. The first step is the formation of the aggregates themselves. The aggregates in the thin layer were huge diatom flocs whose species composition clearly indicated that they were derived from the aggregation of diatoms in the dense diatom bloom within the upper, fresher layer. This diatom bloom began when Frazer River plume water entered the sound on May 27, 1996. The phytoplankton community was dominated by Pseudo-nitzschia spp. and Rhizosolenia hebetata f. semispina and surface salinity was 29.8 psu prior to that time. After May 27, a major shift in composition occurred, dominated by Odontella longicruris, Thalassiosira spp., Asterionellopsis glacialis and Thalassionema nitzschioides, as fresher water flowed into the sound from the Straight of Georgia reducing the salinity of the surface layer to 27.4 psu (Twardowski \& Donaghay 2001, Dekshenieks et al. 2001, Rines et al. 2002). Nearly identical temperature and salinity characteristics of the surface layer (0 to $5 \mathrm{~m}$ ) at the study site from May 29 to 31 indicate that the same surface water mass persisted over the $48 \mathrm{~h}$ prior to our study (Twardowski \& Donaghay 2001). Thus, the dense diatom bloom observed reached maximum development within the sound itself. Since large aggregates were not seen by divers prior to May 31, the bloom probably reached a density high enough for mass aggregation at about that time. 

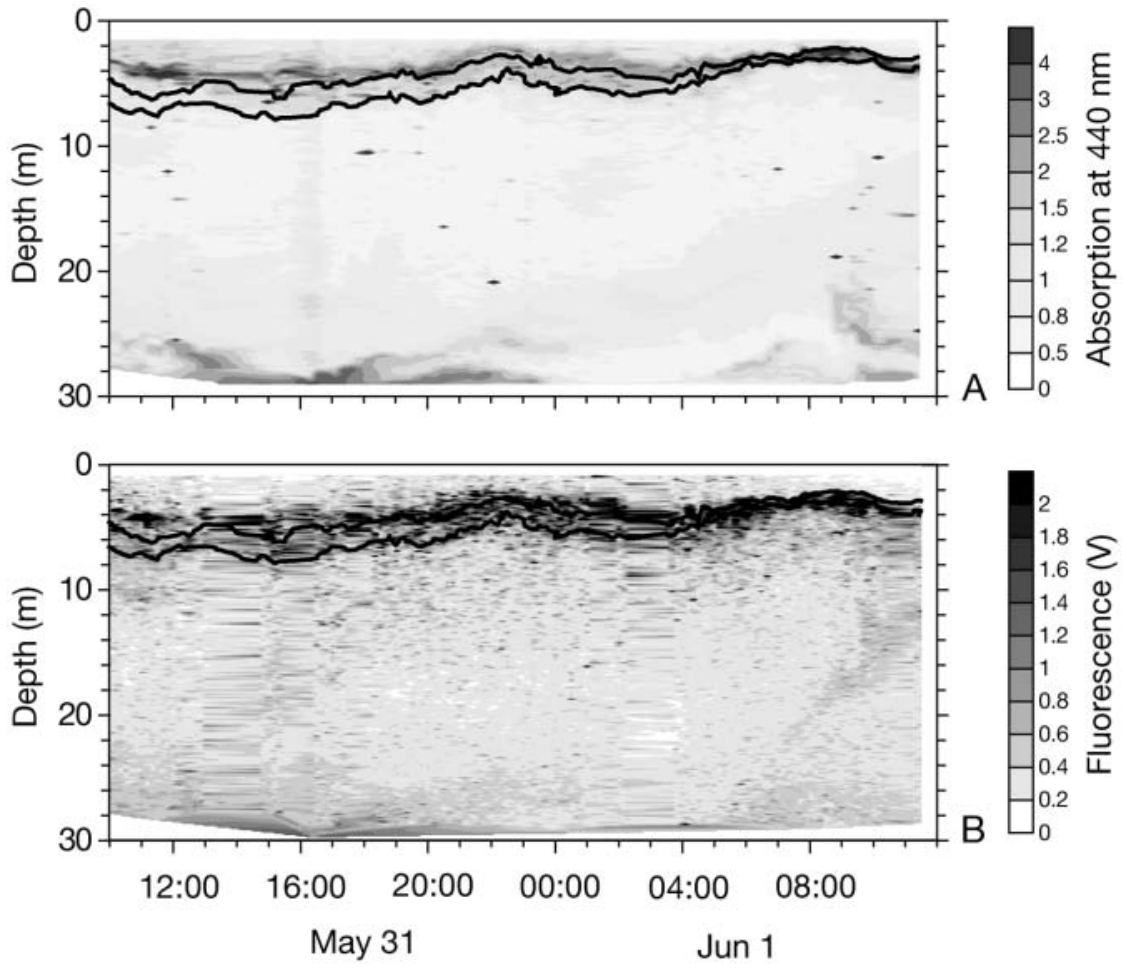

Fig. 6. (A) Particulate absorption at $440 \mathrm{~nm}$ and (B) phytoplankton fluorescence (relative volts) over the $24 \mathrm{~h}$ study. The 21.2 and 21.4 isopycnals of $\sigma_{\mathrm{t}}$ are superimposed as black lines

Diatom bloom aggregation is a well-documented phenomenon among chain-forming diatoms worldwide (Smetacek 1985, Alldredge \& Gotschalk 1989, Alldredge et al. 1995). The higher proportion of Odontella longicruris and the lower proportion of Thalassiosira spp. and Thalassionema nitzschioides within aggregates relative to unaggregated cells suggests that $O$. longicruris differentially aggregated. Differential aggregation may lead to sequential sedimentation of species in a bloom (Crocker \& Passow 1995). Rapid aggregation of $O$. longicruris into large flocs under quiescent conditions has been observed in 201 tanks in the laboratory (J.E.B.R. pers. obs.)

Since the upper layer of the water column was quite shallow $(<7 \mathrm{~m})$ and even small aggregates of $0.5 \mathrm{~mm}$ in diameter sink at rates of 40 to $50 \mathrm{~m} \mathrm{~d}^{-1}$ (Asper 1987, Alldredge \& Gotschalk 1988, Diercks \& Asper 1997), aggregates formed throughout the upper layer would sink relatively rapidly to the depth where they accumulated. It would require $<3 \mathrm{~h}$ for a $0.5 \mathrm{~mm}$ aggregate formed right at the surface to reach a depth of 6 to $7 \mathrm{~m}$ and much less time for larger, more rapidly sinking aggregates to do so (Alldredge \& Gotschalk 1988). As aggregates collided at the accumulation depth, they formed the abundant $\mathrm{cm}$ sized aggregates we observed.
The second step in the formation of a persistent thin layer of marine snow is that the aggregates have to reach neutral density and stop sinking. If this does not occur, then the thin layer will never persist because the aggregates will simply continue sinking and no accumulation will occur. Attainment of neutral buoyancy is a requirement for the persistence of any thin layer of passively sinking particle, regardless of the mechanism initially generating the thin layer. Other mechanisms proposed for the formation of thin layers of suspended particles, in addition to diatom bloom aggregation and sedimentation, include lateral intrusion of water containing high concentrations of particles, the stretching of large patches into thin sheets by laminar vertical shear, erosion of thicker layers by shear (Osborn 1998) and internal waves impacting a sloping seafloor (McPhee-Shaw \& Kunze 2002). However, all these mechanisms still require that marine snow stops sinking if the thin layer is to persist for more than a few min. For example, a $50 \mathrm{~cm}$ thin layer formed by the intrusion of water containing aggregates sinking at 50 to $100 \mathrm{~m} \mathrm{~d}^{-1}$ (3.4 to $7 \mathrm{~cm} \mathrm{~min}^{-1}$ ) would disperse in $<15$ min unless the aggregates were neutrally buoyant.

Alldredge \& Crocker (1995) proposed that neutral buoyancy is attained by an aggregate sinking from a lower salinity surface layer into a halocline if some proportion of the aggregate's interstitial volume is occupied by lower-density mucus which is resistant to the diffusion of salts and water. Such interstitial mucus would form from the gelation and aggregation of polysaccharides (Alldredge et al. 1993, Chin et al. 1998) exuded by the diatoms in the lower-salinity layer. Transparent exopolymer particles (TEP) formed from diatom exudates are very abundant in dense diatoms blooms and have been shown to be necessary for the aggregation of most diatoms (Passow et al. 1994, Logan et al. 1995). As the diatoms aggregate, they incorporate TEP formed in the lower-salinity surface layer into the floc interstices. Alldredge \& Crocker (1995) and MacIntyre et al. (1995) calculated that only 0.5 to $2 \%$ of the interstitial volume of a diatom floc need be occupied by mucus for neutral buoyancy to be achieved in systems where the density difference between the upper layer of mucus formation and the lower layer of accumulation was 1 to $3 \sigma_{\mathrm{t}}$.

The sharp salinity gradient in East Sound produced ideal conditions for the formation of a marine snow thin 


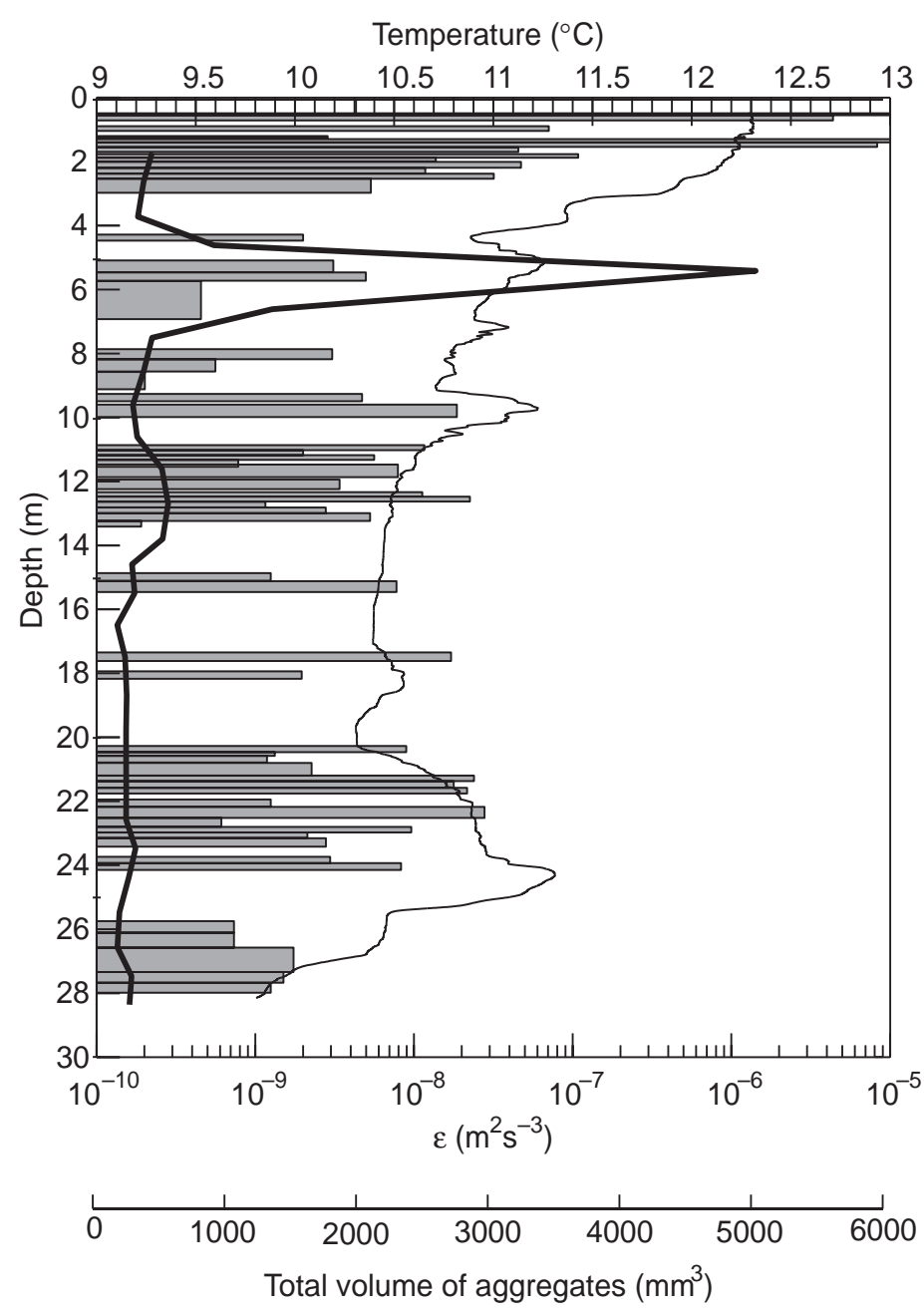

Fig. 7. A typical microstructure profile of the rate of turbulent kinetic energy dissipation ( $\varepsilon$; horizontal bars) taken at 11:00 $\mathrm{h}$ on May 31, 1996. $\varepsilon$ was low at depths of high total aggregate volume (-). Temperature (-) is shown for comparison. Unshaded areas were not turbulent

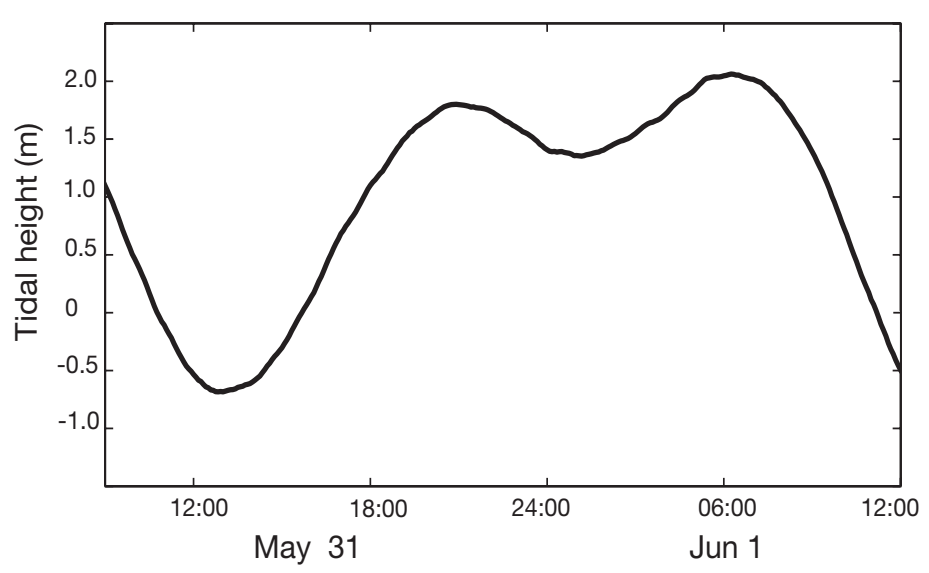

Fig. 8. Tidal height over the study period layer. TEP formed in the lower-salinity upper layer would have a relatively lower density and be resistant to salt diffusion. The thin layer of marine snow observed here rested on the $21.4 \sigma_{\mathrm{t}}$ isopycnal (Fig. 3A), which was $1.4 \sigma_{\mathrm{t}}$ denser than the lower-salinity layer in which the diatoms aggregated. Diatom aggregates containing slightly less than $1 \%$ mucus in their interstitial volume would reach neutral buoyancy at this density difference (see Fig. 2 in Alldredge \& Crocker 1995).

The diatom aggregates observed also contained largely healthy, chain-forming diatoms. Regulation of cell buoyancy by these living cells could also have contributed to attainment of neutral buoyancy. Diatom mats of Rhizosolenia spp. similar in size to the aggregates observed here are known to regulate buoyancy in response to nutrient availability (Villareal et al. 1999), even becoming positively buoyant when nutrientreplete. We would expect nutrient concentrations to be higher at the mixing interface between the 2 water layers, which would facilitate increased cell buoyancy.

The significance of density gradients for the formation of thin layers of marine snow was especially evident after 04:00 $\mathrm{h}$ when an intrusion of warmer water at depth caused all the isopycnals to shoal. The marine snow thin layer also shoaled along with the isopycnal on which it rested. The integrity of the thin layer was also maintained by the low turbulence around it. This turbulence was too low to disperse or erode the layer, or to broaden it. Marine snow is quite strong and energy dissipation rates at least 2 orders of magnitude higher than the $10^{-8} \mathrm{~m}^{2} \mathrm{~s}^{-3}$ observed near the marine snow layer would be required to fragment even the most fragile diatom aggregates (Alldredge et al. 1990).

\section{Ecological impacts of the marine snow thin layer}

Many ecological and trophic consequences are likely to result from highly concentrated thin layers of marine snow. The accumulation of aggregates preferentially enriched in certain diatom species resulted in vertical variations in phytoplankton community structure. Such variations would produce differing rates of speciesspecific nutrient uptake, growth, dissolved organic carbon (DOC) exudation, or photosynthesis. Vertical patchiness in chromophoric dissolved organic matter (CDOM) production (Twardowski \& Donaghay 2001), fine-scale chemical gradients (Hanson \& Donaghay 1998), and phytoplankton taxa known to produce toxic domoic acid (Donaghay et al. 1992, Rines et al. 2002) are associated with algal thin layers. Marine snow thin layers may also be highly concentrated sites of autotrophic processes since marine snow can harbor phytoplankton at concentrations 1 to 3 orders of mag- 

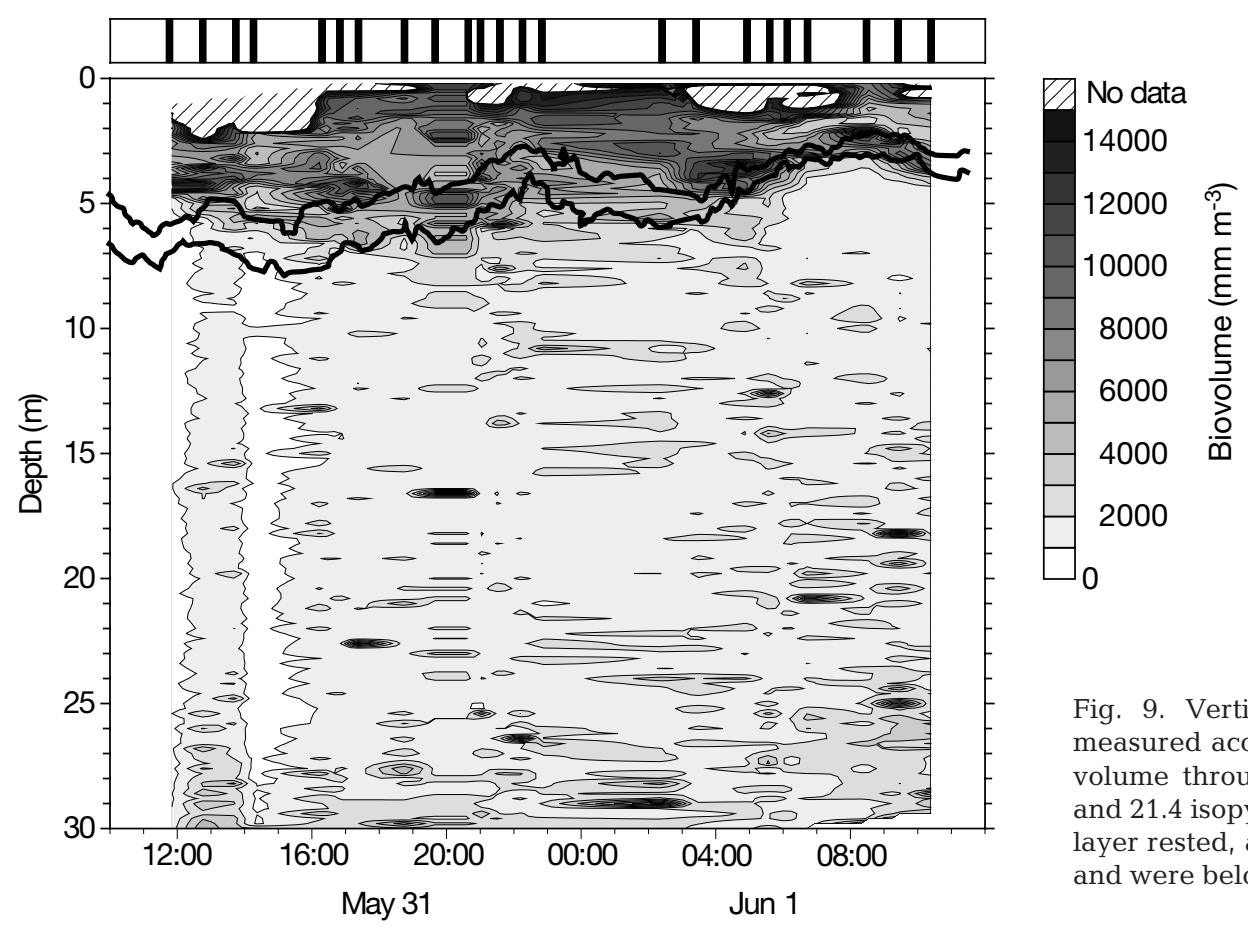

nitude higher than found in the surrounding water (Alldredge \& Silver 1988) and exhibit elevated levels of photosynthesis (Gotschalk \& Alldredge 1989).

Herndl (1988) found elevated levels of microbial activity associated with a marine snow thin layer in the Adriatic Sea indicating that snow layers are sites of enhanced remineralization of carbon and nutrients. Aggregates also contain high concentrations of nutrients and DOC (Shanks \& Trent 1979, Alldredge 2000). These layers may also attract or deter grazers. Laboratory experiments show that copepods can detect and stay within layers of food (Tiselieus 1992) and microzooplankton are known to show patchy and aggregated distributions (Bjornsen \& Nielsen 1991). Most macrozooplankton taxa in this study appeared to avoid the marine snow layer. Although marine snow is readily consumed by many planktonic herbivores (Dilling et al. 1998), concentrations in the thin layer observed in East Sound were so high that feeding may have been inhibited. The abundant TEP within the aggregates may have clogged delicate feeding appendages. It is also possible that the herbivores differentially avoided Odontella, preferring the Thalassiosira and other genera more common in the surface bloom.

The relatively high species diversity in pelagic systems compared to their seeming physical and chemical homogeneity led G. E. Hutchinson to first propose the 'paradox of the plankton' (Hutchinson 1961). Clearly, the ability of organisms to partition the habitat vertically through direct buoyancy responses to density gradients, by association with passively accumulating particles such as marine snow, or through selection for layers high in prey or low in sticky mucus, permits the development of much greater spatial heterogeneity in community structure in the pelagic zone than previously imagined. The persistence of this community structure for several days or more (time scales that are as long or longer than the generation times of many plankton) through the formation and maintenance of thin layers must have profound, but as yet uninvestigated, impacts on the evolution and species diversity of plankton communities.

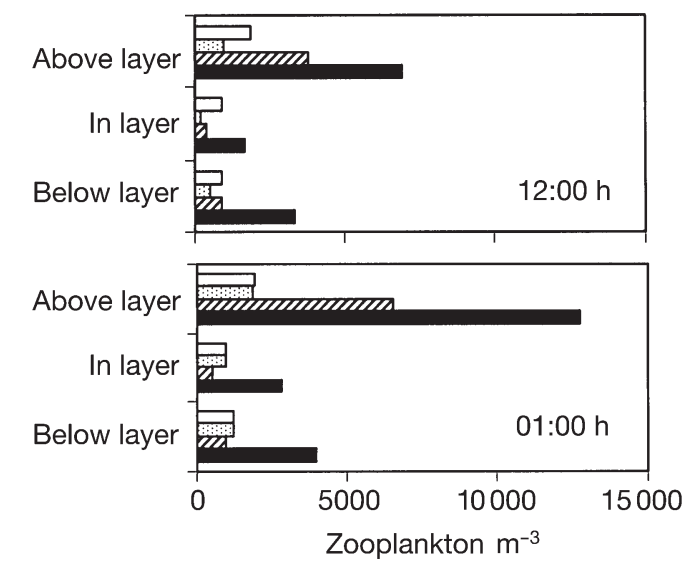

Larvae Gopepods Larvaceans Total zooplankton

Fig. 10. The vertical distribution of zooplankton as determined by diver-towed nets within, directly above, and directly below the thin layer of marine snow at noon, May 30 and shortly after 00:00 h on June 1, 1996 
Moreover, species of organisms associated with marine snow thin layers may be missed by traditional sampling methods, which sample at large vertical intervals. Just as traditional samplers may entirely miss thin layers of phytoplankton (Rines et al. 2002), so Niskin bottles and nets may systematically miss or undersample high concentrations of phytoplankton and microbes associated with concentrated layers of marine snow. There is growing evidence that all components of the water column from dissolved molecules, phytoplankton and bacteria to POM and zooplankton are periodically vertically distributed in the water column in micro-scale layers. The existence of thin layers of marine snow as well as of phytoplankton suggests that the pelagic ecosystem is much more structured than previously imagined.

Acknowledgements. We thank Russ Desiderio, Andrew Barnard, Mike Twardowski, Carol Wyatt, and Lorenz Moosmann for assistance with field observations and data processing. The following grants from the Office of Naval Research supported this research (principal investigator initials in parentheses): N00014-96-1-0069 (A.L.A., S.M.), N00014-9410259 (T.J.C.), N00014-95-1-0211 (P.L.D.), N00014-95-1-0225 (P.L.D.), N00014-98-C-0025 (D.V.H.), N00014960247 (J.E.B.R.), and N00014-98-1-0252 (J.R.V.Z.). ONR support is gratefully acknowledged.

\section{LITERATURE CITED}

Alldredge AL (2000) Interstitial dissolved organic carbon (DOC) concentrations within sinking marine aggregates and their potential contribution to carbon flux. Limnol Oceanogr 45:1245-1253

Alldredge AL, Crocker KM (1995) Why do sinking mucilage aggregates accumulate in the water column? Sci Total Environ 165:15-22

Alldredge AL, Gotschalk CC (1988) In situ settling behavior of marine snow. Limnol Oceanogr 33:339-351

Alldredge AL, Gotschalk CC (1989) Direct observations of the mass flocculation of diatom blooms: characteristics, settling velocities and formation of diatom aggregates. DeepSea Res 36:159-171

Alldredge AL, Silver, MW (1988) Characteristics, dynamics and significance of marine snow. Prog Oceanogr 20:41-82

Alldredge AL, Granata TC, Gotschalk CC, Dickey TD (1990) The physical strength of marine snow and its implications for particle disaggregation in the ocean. Limnol Oceanogr 35:1415-1428

Alldredge AL, Passow U, Logan BE (1993) The abundance and significance of a class of large, transparent organic particles in the ocean. Deep-Sea Res 40:1131-1140

Alldredge AL, Gotschalk CC, Passow U, Riebesell U (1995) Mass aggregation of diatom blooms: insights from a mesocosm study. Deep-Sea Res 42:9-28

Asper VL (1987) Measuring the flux and sinking speed of marine snow aggregates. Deep-Sea Res 34:1-17

Bjornsen PK, Nielsen TG (1991) Decimeter scale heterogeneity in plankton during a pycnocline bloom of Gyrodinium aureolum. Mar Ecol Prog Ser 73:263-267
Carpenter EJ, Janson S, Boje R, Pollehne F, Chang J (1995) The dinoflagellate Dinophysis norvegica: biological and ecological observations in the Baltic Sea. Eur J Phycol 30:1-9

Chin WC, Orellana MW, Verdugo P (1998) Spontaneous assembly of marine dissolved organic matter into polymer gels. Nature 391:568-571

Cowles TJ, Desiderio RA (1993) Resolution of biological microstructure through in situ fluorescence emission spectra. Oceanography 6:105-111

Cowles T, Desiderio RA, Carr ME (1998) Small-scale planktonic structure: persistence and trophic consequences. Oceanography 11:4-9

Crocker K, Passow U (1995) Differential aggregation of diatoms. Mar Ecol Prog Ser 17:249-257

Degobbis D, Fonda-Umani S, Franco P, Malej A, Precali R, Smodlaka N (1997) Microbial activities and the transformation of organic matter within mucilaginous aggregates. Sci Total Environ 165:43-58

Dekshenieks MM, Donaghay PL, Sullivan JM, Rines JEB, Osborn TR, Twardowski MS (2001) Temporal and spatial occurrence of thin phytoplankton layers in relation to physical processes. Mar Ecol Prog Ser 223:61-71

Diercks AR, Asper VL (1997) In situ settling speeds of marine snow aggregates below the mixed layer: Black Sea and Gulf of Mexico. Deep-Sea Res Part I 44:385-398

Dilling L, Wilson J, Steinberg D, Alldredge AL (1998) Feeding of Euphausia pacifica and Calanus pacificus on marine snow. Mar Ecol Prog Ser 170:189-201

Donaghay PL, Osborn TR (1997) Toward a theory of biological-physical control of harmful algal bloom dynamics and impacts. Limnol Oceanogr 42:1283-1296

Donaghay PL, Rines HM, Sieburth JM (1992) Simultaneous sampling of fine scale biological, chemical and physical structure in stratified waters. Ergeb Limnol 36:97-108

Gotschalk CC, Alldredge AL (1989) Enhanced primary production and nutrient regeneration within aggregated marine diatoms. Mar Biol 103:119-129

Greenlaw CF (1979) Acoustical estimation of zooplankton populations. Limnol Oceanogr 24:226-242

Hanson AK, Donaghay PL (1998) Micro- to fine-scale chemical gradients and layers in stratified coastal waters. Oceanography 11:10-17

Herndl GJ (1988) Ecology of amorphous aggregates (marine snow) in the Northern Adriatic Sea. II. Microbial density and activity in marine snow and its implications to overall pelagic processes. Mar Ecol Prog Ser 48:265-275

Herndl GJ, Peduzzi P (1988) The ecology of amorphous aggregates (marine snow) in the Northern Adriatic Sea: I. General considerations. PSZN I: Mar Ecol 9:79-90

Holliday DV, Pieper RE, Greenlaw CF, Dawson JK (1998) Acoustical sensing of small-scale vertical structures. Oceanography 11:18-23

Hutchinson GE (1961) The paradox of the plankton. Am Nat 95:137-145

Johnson PW, Donaghay PL, Small EB, Sieburth JM (1995) Ultrastructure and ecology of Perispira ovum (Ciliophora: Litostomatea): an aerobic, planktonic ciliate that sequesters the chloroplasts, mitochondria, and paramylon of Euglena proxima in a micro-oxic habitat. Euk Microbiol 42:323-335

Logan BE, Passow U, Alldredge AL, Grossart HP, Simon M (1995) Rapid formation and sedimentation of large aggregates is predictable from coagulation rates (half lives) of transparent exopolymer particles (TEP). Deep-Sea Res Part II 42:203-214

MacIntyre S, Alldredge AL, Gotschalk CC (1995) Accumulation of marine snow at density discontinuities in the water column. Limnol Oceanogr 40:449-468 
MacIntyre S, Flynn KM, Jellison R, Romero JR (1999) Boundary mixing and nutrient fluxes in Mono Lake, California. Limnol Oceanogr 44:512-529

Mason RP, Fitzgerald WF, Donaghay PL, Sieburth JM (1993) Mercury speciation and cycling in the Pettaquamscutt Estuary. Limnol Oceanogr 36:1227-1241

McPhee-Shaw EE, Kunze E (2002) Horizontal intrusions generated by internal-wave turbulence along a sloping boundary: a laboratory investigation. J Geophys Res (in press)

Osborn T (1998) Fine structure, microstructure and thin layers. Oceanography 11:36-43

Passow U, Alldredge AL, Logan BE (1994) The role of particulate carbohydrate exudates in the flocculation of diatom blooms. Deep-Sea Res Part I 41:335-357

Rines JEB, Donaghay PL, Dekshenieks MM, Sullivan JM, Twardowski MS (2002) Thin layers and camouflage: hidden Pseudo-nitzschia (Bacillariophyceae) populations in a fjord in the San Juan Islands, Washington, USA. Mar Ecol Prog Ser 225:123-137

Shanks AL, Trent JD (1979) Marine snow: microscale nutrient patches. Limnol Oceanogr 24:850-854

Sieburth JM, Donaghay PL (1993) Planktonic methane production and oxidation within the algal maximum of the

Editorial responsibility: Otto Kinne (Editor),

Oldendorf/Luhe, Germany pycnocline: seasonal fine scale observations in an anoxic estuarine basin. Mar Ecol Prog Ser 100:3-15

Smetacek V (1985) Role of sinking in diatom life-history cycles: ecological, evolutionary and geological significance. Mar Biol 84:239-251

Stachowitsch M, Funuko N, Richter MY (1990) Mucus aggregates in the Adriatic Sea: an overview of stages and occurrences. PSZN I: Mar Ecol 11:327-350

Tiselieus P (1992) Behavior of Acartia tonsa in patchy food environments. Limnol Oceanogr 37:1640-1651

Twardowski MS, Donaghay PL (2001) Separating in situ and terrigenous sources of absorption by dissolved materials in coastal waters. J Geophys Res 106: 2545-2560

Twardowski MS, Sullivan JM, Donaghay PL, Zaneveld JRV (1999) Microscale quantification of the absorption by dissolved and particulate material in coastal waters with an ac-9. J Atmos Oceanic Technol 16:691-707

Villareal TA, Pilskaln C, Brzezinski M, Lipschultz F, Dennett M, Garner GB (1999) Upward transport of organic nitrate by migrating diatom mats. Nature 397:423-425

Zaneveld JRV, Pegau WS (1998) A model for reflectance of thin layers, fronts, and internal waves and its inversion. Oceanography 11:44-47

Submitted: June 27, 2001; Accepted: November 27, 2001 Proofs received from author(s): April 22, 2002 